\title{
Estimation of stature from arm span using regression equation in Dehradun region
}

\author{
Jyoti Barwa ${ }^{1}$, Rattan Singh ${ }^{2 *}$ \\ ${ }^{1,2}$ Assistant Professor, ${ }^{1,2}$ Dept. of Forensic Medicine and Toxicology, ${ }^{1}$ Shri Suru Ram Rai Institute of Medical and Health Science, Patel \\ Nagar, Dehradun, Uttarakhand, ${ }^{2}$ Himalayan Institute of Medical \& Health sciences, SRHU, Jolly Grant, Dehradun, India
}

\section{Corresponding Author: Rattan Singh}

Email: dr.rattan.singh2004@gmail.com

\begin{abstract}
Background: Stature can be easily estimated using various anthropometric parameters like arm span, facial dimensions, foot length and breadth, vertebral column length etc. Among these, arm span has been proven to be one of the most reliable predictors.

Materials and Methods: The study was conducted in Shridev Suman Subharti Medical College, Dehradun among a total of 100 healthy subjects (17-25 years), comprising 50 males and 50 females. Those with history of any fracture involving long bones or presence of any spinal deformity were excluded from the study. Stature and arm span was measured directly using anthropometric technique and measuring tape. The correlation between stature and arm span was determined and regression equations were calculated for stature estimation.

Observations and Result: There was a strong positive correlation between mean height and arm span in total subjects as well as in both sexes which showed statistical significance. $(r=0.826$ for male, $r=0.750$ for female; $p<0.05)$. Linear regression equations were obtained for total subjects as well as for both sexes for determination of stature.

Conclusion: Stature has a very high, positive correlation with arm span; regression equation can be easily calculated using these variables which can be used as a potential parameter in identification.
\end{abstract}

Keywords: Stature, Arm span, Identification.

\section{Introduction}

Stature is one of the essential parameters of identification which is often calculated from anthropometric measurements such as long bones, facial dimensions, sternum, vertebral column length, length of scapula, limb and foot ${ }^{1,2}$ In situations when it is not feasible to measure stature due to deformities/ amputations of limbs or in unknown bodies where lower limb and / or trunk is absent; stature can be estimated using such parameters ${ }^{3,4}$

These measurements represent certain relationship in the form of proportion to stature and once skeletal maturity is attained, they do not alter. ${ }^{1,5,6}$ However, other factors such as inheritance, climate, nutrition also influence growth and development of an individual to a great extent including total height as well as length of long bones. Among the various parameters, arm span is considered to be the most reliable body indicator for predicting the body height of an individual $^{7,8}$ In India, due to diversity of ethnic groups residing in varied climatic \& ecological conditions, this relationship also varies from one region to another. ${ }^{1}$

\section{Materials and Methods}

The study was conducted in Shridev Suman Subharti Medical College, Dehradun among 100 (50 males \& 50 females) healthy students of the Institute, varying in age from 17-25yrs. Those having any spinal/ skeletal deformity, physical disablity, past history of skeletal injuries affecting bones and those in any form of hormonal medications were excluded from the study. A written informed consent was obtained; procedure and purpose of study was explained to all the participants.
Stature was measured as the vertical distance from the vertex to the floor using a standard anthropometer. The subjects were made to stand erect on a horizontal resting plane, barefooted. Anthropometer was placed in straight vertical position behind the subject with the head oriented in the Frankfurt plane \& shoulders \& hips touching the vertical limb of the instrument. The movable rod of the anthropometer was brought in contact with the vertex in the midsagittal plane. Full length of both the arms, when outstretched horizontally (armspan) with both arms abducted to $90^{\circ}$, elbows and wrists extended and the palms facing directly forward, was noted using a measuring tape till tip of middle finger on each side. It was noted by a single observer, twice and an average was duly noted, to minimise subjective errors. Subsequently, using statistical software SPSS version 20, simple linear regression equations formulated for determining stature.

\section{Observation and Results}

The study showed a positive correlation between mean height and arm span in total subjects as well as in both sexes. [Fig. 1-3] This correlation was found to be statistically significant as $\mathrm{p}<.05$ in all the parameters. $(\mathrm{r}=$ 0.95 for total, $r=0.826$ for male, $r=0.750$ for female) The males having stature of $175.42 \pm 5.99 \mathrm{~cm}$ had the arm span of $179.54 \pm 6.84 \mathrm{~cm}$ and females having stature of $166.07 \pm 10.88 \mathrm{~cm}$ had the arm span of $168.66 \pm 12.51 \mathrm{~cm}$. Linear regression equation was obtained for total subjects as well as for both sexes from which stature can be calculated. [Table 1] 


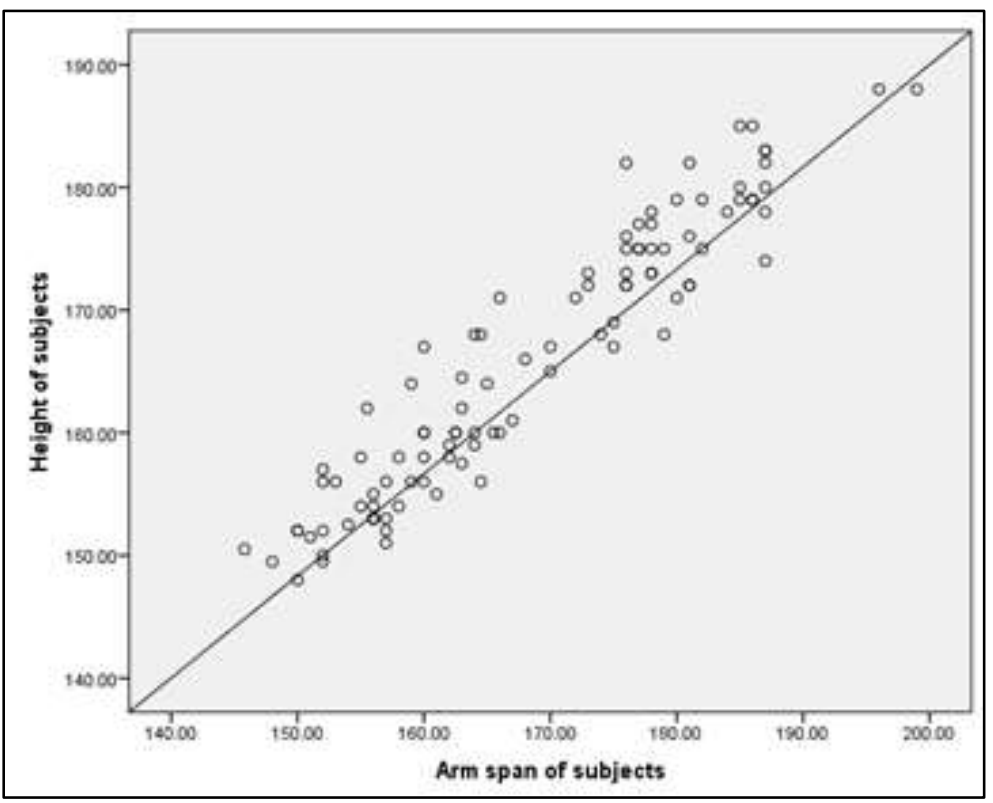

Fig. 1: Scatter diagram showing correlation in between height in total subjects and Arm span in total subjects

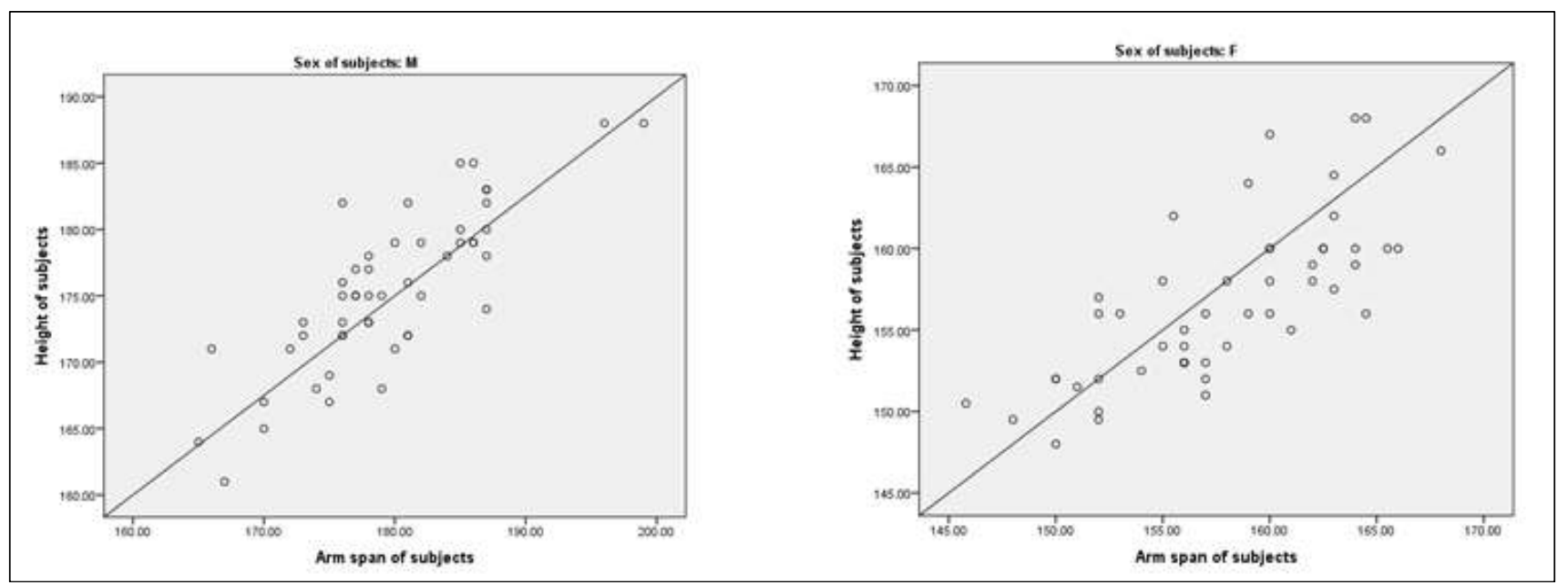

Fig. 2 \& 3: scatter diagram showing correlation in between height and Arm span in male and female

Table 1: Regression analysis for predicting stature(y) of subjects (dependable variable) considering arm span as an independent variable

\begin{tabular}{|c|c|c|c|c|c|c|c|}
\hline S. No. & parameter & mean & $\begin{array}{c}\text { Std. } \\
\text { deviation }\end{array}$ & $\begin{array}{l}\text { Correlat } \\
\text { ion value }\end{array}$ & $\begin{array}{c}\mathbf{p} \\
\text { value }\end{array}$ & $\begin{array}{c}\mathbf{r} \\
\text { square }\end{array}$ & Regression equation \\
\hline \multirow{2}{*}{$\begin{array}{c}\text { Total } \\
\text { subjects } \\
(\mathrm{n}=100)\end{array}$} & Mean height & 166.07 & 10.88 & \multirow[b]{2}{*}{.95} & \multirow[b]{2}{*}{.00} & \multirow[b]{2}{*}{.902} & \multirow{2}{*}{$\begin{array}{l}\mathrm{y}=26.711+0.826 \text { (arm span } \\
\text { in total subjects) }\end{array}$} \\
\hline & $\begin{array}{l}\text { Mean arm } \\
\text { span }\end{array}$ & 168.66 & 12.51 & & & & \\
\hline \multirow{2}{*}{$\begin{array}{c}\text { Male } \\
\text { subjects } \\
(\mathrm{n}=50)\end{array}$} & Mean height & 175.42 & 5.99 & \multirow[b]{2}{*}{.826} & \multirow[b]{2}{*}{.00} & \multirow[b]{2}{*}{.683} & \multirow{2}{*}{$\begin{array}{l}y=153.706+6.003 \text { (arm } \\
\text { span in male subjects) }\end{array}$} \\
\hline & $\begin{array}{c}\text { Mean arm } \\
\text { span }\end{array}$ & 179.54 & 6.84 & & & & \\
\hline \multirow{2}{*}{$\begin{array}{c}\text { Female } \\
\text { subjects } \\
(\mathrm{n}=50)\end{array}$} & Mean height & 156.73 & 5.00 & \multirow[b]{2}{*}{.750} & \multirow{2}{*}{.00} & \multirow{2}{*}{.563} & \multirow{2}{*}{$\begin{array}{l}\mathrm{y}=43.794+0.716 \text { (arm spar } \\
\text { in female subjects) }\end{array}$} \\
\hline & $\begin{array}{l}\text { Mean arm } \\
\text { span }\end{array}$ & 157.78 & 5.24 & & & & \\
\hline
\end{tabular}


Table 2: comparison of studies by various authors

\begin{tabular}{|c|c|c|c|c|c|}
\hline S.no. & Authors & year & Gender & $\begin{array}{l}\text { Coffecient of } \\
\text { correlation (r) }\end{array}$ & Regression equation (Y) \\
\hline 1 & Present study & 2019 & $\begin{array}{l}\text { Total } \\
\text { Male } \\
\text { Female }\end{array}$ & $\begin{array}{l}0.95 \\
0.826 \\
0.750\end{array}$ & $\begin{array}{c}26.711+0.826(\mathrm{AS}) \\
153.706+6.003(\mathrm{AS}) \\
43.794+0.716(\mathrm{AS})\end{array}$ \\
\hline 2 & Dongare SS et al & 2017 & $\begin{array}{c}\text { Total } \\
\text { Male } \\
\text { Female }\end{array}$ & $\begin{array}{l}0.9187 \\
0.8443 \\
0.9187\end{array}$ & $\begin{array}{c}34.752+0.7796(\mathrm{AS}) \\
50.56+0.6865(\mathrm{AS}) \\
34.752+0.7796(\mathrm{AS})\end{array}$ \\
\hline 3 & Alam MT et al & 2016 & $\begin{array}{c}\text { Total } \\
\text { Male } \\
\text { Females }\end{array}$ & $\begin{array}{l}0.798 \\
0.689 \\
0.783\end{array}$ & $\begin{array}{l}48.91+0.703(\mathrm{AS}) \\
36.19+0.775(\mathrm{AS}) \\
60.68+0.630(\mathrm{AS})\end{array}$ \\
\hline 4 & Sah RP et al & 2013 & $\begin{array}{c}\text { Males } \\
\text { Females }\end{array}$ & $\begin{array}{l}0.682 \\
0.507\end{array}$ & - \\
\hline 5 & Chawla $\mathrm{M}$ et al & 2013 & Male & 0.897 & $44.0912+0.9987(\mathrm{AS})$ \\
\hline 6 & Goon TD et al & 2011 & $\begin{array}{c}\text { Males } \\
\text { Females }\end{array}$ & $\begin{array}{l}0.77 \\
0.72 \\
\end{array}$ & $\begin{array}{c}67.63+0.577(\mathrm{AS}) \\
55.16+.642(\mathrm{AS}) \\
\end{array}$ \\
\hline 7 & Zverev et al & 2003 & $\begin{array}{c}\text { Males } \\
\text { Females }\end{array}$ & $\begin{array}{l}0.871 \\
0.815\end{array}$ & - \\
\hline 8 & Aggarwal et al & 2000 & $\begin{array}{l}\text { Total } \\
\text { Male } \\
\text { female }\end{array}$ & $\begin{array}{l}0.8226 \\
0.6473 \\
0.7094\end{array}$ & $\begin{array}{l}33.837+0.776(\mathrm{AS}) \\
50.818+0.681(\mathrm{AS}) \\
40.233+0.731(\mathrm{AS})\end{array}$ \\
\hline 9 & Brown et al & 2000 & - & 0.84 & $\begin{array}{c}0.68 \text { (arm span) }-3.55 \text { (gender) }- \\
3.81 \text { (race) }-0.02(\text { age })+55.34\end{array}$ \\
\hline 10 & Reeves et al & 1996 & $\begin{array}{l}\text { Afrocarribean male } \\
\text { Asian male }\end{array}$ & $\begin{array}{l}\text { Varying from } \\
0.73 \text { to } 0.89\end{array}$ & $\begin{array}{l}66.9+0.57(\mathrm{AS}) \\
81.0+0.48(\mathrm{AS}) \\
\end{array}$ \\
\hline
\end{tabular}

\section{Discussion}

A number of studies have been conducted demonstrating the positive correlation between arm span and height using regression analysis. ${ }^{6,10-17}$ [Table 2] As depicted, the high values of regression coefficient signify that arm span is reliable and significantly predicts body height in all these studies; infact it is the closest physiologic measurement to standing height.

Though, most of the authors have taken only male population into consideration, our study involves both the sexes as well as the total population. Among those, who have taken both males and females into account, in studies by some authors ${ }^{10,14,15}$ stature showed a better correlation in males as compared to females, which is in concordance with our study. While some authors ${ }^{18,19}$ have reported that arm span is more accurate in females than in males. Still others have reported no differences between males and females. ${ }^{20}$ However, only a few of the authors ${ }^{4}$ failed to calculate any regression equation for estimating stature. [Table 2]

In our study, a wider age group was not considered; use of age as an additional predictor variable in the past studies shows a very small amount of variance in regression equations with no significant correlation between age and height arm ratio. There is considerable reduction in height with advancing age due to degenerative changes in the spine while the measure of arm span remains as such. Thus, age is not considered a major predictor for estimation of height from arm span. . $^{10,21,22}$

\section{Conclusion}

In situations when exact height cannot be determined directly due to deformities of lower limb, amputation or shortening as a result of fractures; arm span can be measured and stature can be easily estimated with high reliability from regression equation. This method is beneficial not only in forensic investigation but also in predicting age related loss of stature and in determining any disproportionate growth abnormalities along with calculation of basic energy requirements, standardization of measures of physical capacity and for adjusting dosages of drugs. ${ }^{4,6}$

Ethical Clearance: Obtained from Institutional Ethical Committee

\section{Conflict of Interest: None}

\section{Funding: self}

\section{References}

1. Bhatnagar DP, Thapar SP, Batish MK. Identification of personal height from the somatometry of the hand in Punjabi males. Forensic Sci Int 1984;24(2):137-41.

2. Singh R, Barwa J, Nanda R,Mamgain S, Sabharwal S, Chadha $S$, Kataria $S$ et al. Estimation of stature from percutaneous measurement of upper limb length by linear regression equation. Medico-Legal Update 2017;17(2):93-6.

3. Shah RK, Nirvan AB, Patel JP, Patel B, Kanani S. Estimating stature from arm span measurement in Gujarat Region. GCSMC J Med Sci 2013;2(2):1330-32. 
4. Shah RP, Kumar A, Bhaskar RK. Body height and its estimation utilizing arm span measurements in population of Birgunj Area of Nepal: An Anthropometric study. J Coll Med Sci-Nepal 2013; 9(4):9-14.

5. Datta B, Sudip. Arm span as a proxy measure for height and estimation of nutritional status: A study among Dhimals of Darjeeling in West Bengal India. Ann Human Biol 2011;38(6):728-35.

6. Chawla M, Rajkumar, Tomar S, Ashoka A. Relationship between arm span and height in adult males of north Indian Punjabi population. J Evol Med Dent Sci 2013;2(4);332-9.

7. Mohanty S.P.,Sreekumaran Nair S. S.B\&S. The use of arm span as a predictor of height. A study of South Indian women. J Orthop Surg 2001; 9(1):19-23.

8. Rao J, Sowmya J, K. Yoganarasimha R. Menezes,T, Kanchan $\&$ Aswinidutt A. 2009. Estimation of stature from cranial sutures in a South Indian male population. Int J Legal Med 2009;123(3): 271-6.

9. Alam MT, Singh S, Rai R, Shaheen S. Correlation between Stature and Arm Span: A Prospective Regional Study in Eastern Uttar Pradesh. Ann Int Med Den Res 2016;2(3):56-60.

10. Aggarwal AN, Gupta D, Ezekiel LM et al. Statistical estimation of height from arm span in North Indian subjects. Indian J Physiol Pharmacol 2000; 44(3):329-34.

11. Brown JK, Feng JY, Knapp TR. Is self-reported height or arm span a more accurate alternative measure of height. Clin Nurs Res 2002;11(4):417-32.

12. Reeves SL, Varakamin C, Henry CJ. The relationship between arm-span measurement and height with special reference to gender and ethnicity. Eur J Cunn Nutr 1996;50(6)398-400.

13. Goon DT, Toriola AL, Musa DI, Akusu S. The relationship between arm span and stature in Nigerian adults. Kinesiology 2011;43(1):38-43.
14. Brown, J. K., Whittemore, K. T., \& Knapp, T. R. Is arm span an accurate measure of height in young and middle-aged adults? Clin Nurs Res 2000;9:84-94.

15. Sah RP, Kumar A, Bhaskar RK. Body height and its estimation utilizing arm span measurements in population of Birgunj Area of Nepal: An Anthropometric study. J Coll Med Sci-Nepal 2013;9(4): 9-14.

16. Dongare SS, Deokar RB, Patil SS, Jadhav PL. Int J Educ Res Health Sci 2017;3(2):64-70

17. Patil TR, Dakhane PS, Bendale N. Stature estimation of the individual using arm span measurement in Jalgaon region of north Maharashtr. Int $j$ Anat Res 2018;6(3.2):5535-7.

18. Engstrom, F. M., Roche, A. F., \& Mukherjee, D. Differences between arm span and stature in white children. $J$ Adolesc Health Care 1981;2:19-22.

19. Kwok, T., \& Whitelaw, M. N. The use of arm span in nutritional assessment of the elderly. J Am Geriatr Soc 1991;39: 492-6.

20. Aggarwal, A. N., Gupta, D., \& Jindal, S. K. Interpreting spirometric data: Impact of substitution of arm span for standing height in adults from North India. Chest 1999;115:557-62.

21. Linderholm H, Lindgren U. Prediction of spirometric values in patients with scoliosis. Acta Orthop Scand 1978;49: 469-74.

22. Brown JK, Feng JY, Knapp TR. Is self-reported height or arm span a more accurate alternative measure of height. Clin Nurs Res 2002;11(4):417-32

How to cite this article: Barwa $J$, Singh R. Estimation of stature from arm span using regression equation in Dehradun region. Int J Forensic Med Toxicol Sci 2019;4(2):56-9. 